\title{
Detection of epidermal growth factor receptor mutations in formalin fixed paraffin embedded biopsies in Malaysian non-small cell lung cancer patients
}

\author{
Tiffany Ng Shi Yeen ${ }^{1}$, Rajadurai Pathmanathan², Mohd Sidik Shiran ${ }^{3}$, Fattah Azman Ahmad Zaid ${ }^{4}$ \\ and Yoke Kqueen Cheah ${ }^{1 *}$
}

\begin{abstract}
Background: Somatic mutations of the epidermal growth factor receptor (EGFR) are reportedly associated with various responses in non-small cell lung cancer (NSCLC) patients receiving the anti-EGFR agents. Detection of the mutation therefore plays an important role in therapeutic decision making. The aim of this study was to detect EGFR mutations in formalin fixed paraffin embedded (FFPE) samples using both Scorpion ARMS and high resolution melt (HRM) assay, and to compare the sensitivity of these methods.
\end{abstract}

Results: All of the mutations were found in adenocarcinoma, except one that was in squamous cell carcinoma. The mutation rate was $45.7 \%$ (221/484). Complex mutations were also observed, wherein 8 tumours carried 2 mutations and 1 tumour carried 3 mutations.

Conclusions: Both methods detected EGFR mutations in FFPE samples. HRM assays gave more EGFR positive results compared to Scorpion ARMS.

Keywords: EGFR, Scorpion ARMS, HRM

\section{Background}

Lung cancer is the main cause of cancer-related death worldwide, with over one million deaths per year [1]. Lung carcinoma is divided into two groups - non-small cell lung cancer (NSCLC) and small cell lung cancer (SCLC), based on its clinical and histopathological features. The NSCLC accounts for about $80 \%$ of lung cancer and can be further divided into three subclasses: adenocarcinoma; squamous cell carcinoma; and large cell carcinoma. In Malaysia, of all the cancer cases, lung cancer ranked second in males and sixth in females [2]. Despite advances in molecular pathology and improvement in screening programs, patients' prognosis remains poor. Most lung cancer patients are diagnosed in the advanced or metastatic stages with a median survival of

\footnotetext{
* Correspondence: ykcheah@medic.upm.edu.my

${ }^{1}$ Department of Biomedical Sciences, Faculty of Medicine and Health Sciences, Universiti Putra Malaysia, 43400, Serdang, Selangor, Malaysia Full list of author information is available at the end of the article
}

about 4-5 months while the 1-year survival rate is less than $10 \%$, if left untreated [3].

Epidermal growth factor receptor $(E G F R)$ is a transmembrane glycoprotein encoded by a gene located at the short arm of chromosome 7. Activation of the receptor through the binding of a ligand stimulates a range of cellular functions such as cell proliferation, differentiation, adhesion, migration and survival. Mutation in the $E G F R$ would result in continuous tyrosine kinase activity regardless of the presence of stimulus which in turn, leads to the development of lung tumours [4]. In 2004, EGFR mutations in NSCLC were discovered to be associated with patients' responsiveness to epidermal growth factor receptor (EGFR) tyrosine kinase inhibitors (TKI) [5-7]. Since then, EGFR mutation has become an important biomarker in lung cancer screening as identifying this biomarker can predict which patient will benefit from EGFR targeted therapy [8].

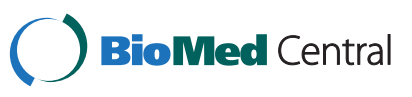


Previous studies showed that EGFR mutations are more common in tumours from female patients, Asian origin, never-smoker and adenocarcinoma histology $[6,9]$. These mutations were reported to be found in exon 18 to 21 located in the intracellular TK-containing domain. Approximately $90 \%$ of the mutations were detected in the following two hotspots: in-frame deletions in exon 19 and a missense mutation at codon 858 $(L 858 R)$ in exon $21[7,10,11]$. These mutations are often termed classical activating mutations [12]. Besides classical mutations, other non-classical mutations in exon 18 to 21 have also been reported. They include point mutations in exon 18 (G719X) and exon 21 (L861Q), as well as substitution mutation $(S 768 I)$ and insertions in exon 20. It is uncommon to detect non-classical mutations and patients harbouring these mutations have variable responses to EGFR TKIs. Moreover, there were cases of complex mutations pattern whereby two or more concomitant sites of EGFR mutations co-exist within a single patient [13-15].

Because of the high rates of EGFR mutation in Asian populations, routine EGFR mutation testing is essential to identify which patient will benefit from the EGFR targeted therapy. Direct sequencing has been the most widely used method in EGFR mutation testing as this method has the capability of detecting all mutations, both known and unknown. However, its time consuming and limited sensitivity due to contamination of nonmalignant cells in samples render researchers to look for alternative testing methods that are faster and more sensitive [16,17].

The Scorpion Amplification Refractory Mutation System (ARMS) combines two technologies, namely ARMS and Scorpion, to detect EGFR mutations in real-time PCR reactions. ARMS allows allele specific amplification while Scorpion molecules which consist of PCR primer, covalently linked to a probe held in a hairpin loop conformation by the presence of complementary stem sequence at the $5^{\prime}$ and $3^{\prime}$ ends. When both technologies are used in combination, a highly sensitive and fast method in single-base mutation detection was achieved [18,19].

Using the Scorpion ARMS kit and HRM assay, we aim to detect major EGFR mutations and to determine the reliability between the two methods in EGFR mutation detection.

\section{Methods}

\section{Patients}

Tumour samples, in the form of unstained sections from formalin fixed, paraffin-embedded (FFPE) tissue block, from patients with NSCLC were received in Sime Darby Medical Centre, Subang Jaya, Malaysia. The samples were assessed by pathologists from Sime Darby Medical
Centre prior to the testing. A total of 484 patients were recruited for this study. Of the 484 samples, 467 were adenocarcinoma, 12 were squamous cell carcinoma, 3 were large cell carcinoma, and 2 were of other histology. This study was approved by Sime Darby independent ethics committee (IRB reference number: 201102.3), by Universiti Putra Malaysia ethics committee (Reference number: UPM/FPSK/PADS/T7-MJKEtikaPer/F01 (JSB_Aug(11)03)) and National Institute of Health, Malaysia (Date: 1207-2011).

\section{DNA extraction}

Genomic DNA was isolated from FFPE tissue section using QIAamp DNA FFPE Tissue Kit (QIAGEN) according to the manufacturer's instructions. Extracted DNA was spectrophotometrically quantified using NanoPhotometer (Implen) and was stored at $-20^{\circ} \mathrm{C}$ until use.

\section{EGFR mutation detection}

EGFR PCR Kit (QIAGEN Manchester Ltd., United Kingdom), which combined two technologies, the Amplification Refractory Mutation System (ARMS) and Scorpion, was used to detect mutations in real-time PCR reactions. All reactions were done in $25 \mu \mathrm{l}$ volumes using $5 \mu \mathrm{l}$ of template DNA, $16 \mu \mathrm{l}$ of reaction mix, $0.2-$ $0.8 \mu \mathrm{l}$ of Taq polymerase and PCR grade water.

\section{HRM assays}

PCR for HRM analysis was performed in $0.2 \mathrm{ml}$ tubes on the Rotor-Gene 6000 using KAPA HRM FAST PCR kit. The reaction mixture in a $20 \mu$ linal volume contained; $1 \times$ KAPA HRM FAST master mix, $2.5 \mathrm{mM}$ $\mathrm{MgCl}_{2}, 200-400 \mathrm{nM}$ forward primer, 200-400 nM reverse primer, $5 \mathrm{ng}$ of genomic DNA and PCR grade water. The cycling and melting conditions for EGFR exons 18 to 21 were as follow; one cycle of $95^{\circ} \mathrm{C}$ for $15 \mathrm{~min}$; $50-70$ cycles of $95^{\circ} \mathrm{C}$ for $10 \mathrm{~s}, 65^{\circ} \mathrm{C}$ for $10 \mathrm{~s}$ with an initial 10 cycles of touchdown $\left(1^{\circ} \mathrm{C} /\right.$ cycle $), 72^{\circ} \mathrm{C}$ for $30 \mathrm{~s}$; one cycle of $97^{\circ} \mathrm{C}$ for $1 \mathrm{~min}$ and a melt from $70^{\circ} \mathrm{C}$ to $95^{\circ} \mathrm{C}$ rising $0.2^{\circ} \mathrm{C}$ per second [20]. All samples were tested in duplicates.

Primer sequences that yield shorter amplicons were used in HRM assays. The sequences, retrieved from Do et al. (2008), are shown in Table 1. Primer for exon 20 was divided into two fragments (20a and 20b) to avoid the exonic SNP, c.2361G>A, because melting pattern arising from the SNP could not be readily extinguished from mutation by HRM.

\section{HRM analysis}

Data were analysed using the accompanying software (Rotor Gene). All samples were plotted according to their melting profiles. Under the difference graph, melting profiles of the samples were compared to that of the 
Table 1 HRM primer sequences

\begin{tabular}{|c|c|c|c|}
\hline Exon & Primer name & Sequence & $\begin{array}{l}\text { Amplicon } \\
\text { size }\end{array}$ \\
\hline \multirow[t]{2}{*}{18} & EGFR_ex18_F & 5'-CATGGTGAGGGCTGAGGTGA-3' & $199 \mathrm{bp}$ \\
\hline & EGFR_ex18_R & $\begin{array}{l}5^{\prime}-C C A G A G G\left(A^{*}\right) \text { CTGTGCCAGGG } \\
\text { AC-3' }\end{array}$ & \\
\hline \multirow[t]{2}{*}{19} & EGFR_ex19_F & 5'-GTGCATCGCTGGTAACATCCA-3 & $250 \mathrm{bp}$ \\
\hline & EGFR_ex19_R & 5'-AAAGGTGGGCCTGAGGTTCA-3 & \\
\hline \multirow[t]{2}{*}{$20 a$} & EGFR_ex20a_F & 5'-AAGCCACACTGACGTGCCTCT-3' & $121 \mathrm{bp}$ \\
\hline & EGFR_ex20a_R & 5'-GCGTGATGAG(G*)TGCACGGT-3' & \\
\hline \multirow[t]{2}{*}{$20 \mathrm{~b}$} & EGFR_ex20b_F & $5^{\prime}$-CCTCCACCGTGCA(C*) CTCATC-3' & $146 \mathrm{bp}$ \\
\hline & EGFR_ex20b_R & 5'-CCCGTATCTCCCTTCCCTGA-3' & \\
\hline \multirow[t]{2}{*}{21} & EGFR_ex21_F & 5'-CCTCACAGCAGGGTCTTCTCTG-3' & $210 \mathrm{bp}$ \\
\hline & EGFR_ex21_R & 5'-TGGCTGACCTAAAGCCACCTC-3' & \\
\hline
\end{tabular}

wild-type which was converted to a horizontal line. Significant deviations from the horizontal line indicate the presence of mutation and were recorded as HRM positive. HRM results were compared with results from Scorpion ARMS method to evaluate the sensitivity of the methods in EGFR mutation detection.

\section{Statistical analysis}

Chi-square test or Fisher exact tests (SPSS version 16.0; SPSS Inc., Chicago, Ill) were used to compare EGFR mutation status with clinicopathologic characteristics and patient's demographic including gender, smoking status, and ethnicity. An interrater reliability analysis using the Kappa statistic was performed to determine consistency between the two methods, Scorpion ARMS and HRM.

\section{Results}

\section{Patient characteristics}

From January 2011 through April 2012, a total of 484 patients with non-small cell lung cancer were tested for EGFR mutations. Patient's clinical characteristics and their association with EGFR mutation are shown in Table 2.

Among these, 467 patients had adenocarcinoma, 12 patients had squamous cell carcinoma, 3 patients had large cell carcinoma, and 2 patients had adenosquamous carcinoma. Among the patients with adenocarcinoma, 220 cases were found to harbour at least 1 mutation in the $E G F R$ gene. And in the remaining 17 nonadenocarcinoma cases, only one had an EGFR mutation, and it occurred in a female patient with squamous cell carcinoma.

Mutations in the EGFR gene were found in 221 of 484 patients $(45.7 \%)$ and were more frequent in women $(60.6 \%, \mathrm{p}<0.001)$ and in patients with adenocarcinoma histology $(47.1 \%, \mathrm{p}=0.004)$. Although not statistically significant, the frequency of EGFR mutations was higher in Chinese (46.4\%), in patients aged less than or equal to
Table 2 Association of each variable with EGFR mutation

\begin{tabular}{|c|c|c|c|}
\hline Characteristics & No. & EGFR mutation No. (\%) & $P$ \\
\hline Patients & 484 & $221(45.7)$ & \\
\hline \multicolumn{4}{|l|}{ Gender } \\
\hline Male & 253 & $81(32.0)$ & \multirow[t]{3}{*}{$<0.001$} \\
\hline Female & 231 & $140(60.6)$ & \\
\hline Missing data & 0 & & \\
\hline \multicolumn{4}{|l|}{ Age, yr } \\
\hline$\leq 60$ & 244 & $119(48.8)$ & \multirow[t]{5}{*}{0.163} \\
\hline$>60$ & 238 & $101(42.4)$ & \\
\hline Median & 60 & & \\
\hline Range & $21-92$ & & \\
\hline Missing data & 2 & & \\
\hline \multicolumn{4}{|l|}{ Ethnicity } \\
\hline Chinese & 293 & $136(46.4)$ & \multirow[t]{5}{*}{0.747} \\
\hline Malay & 143 & $62(43.4)$ & \\
\hline Indian & 26 & $15(57.7)$ & \\
\hline Others & 7 & $2(28.6)$ & \\
\hline Missing data & 15 & $6(40.0)$ & \\
\hline \multicolumn{4}{|l|}{ Stage } \\
\hline |/ $\|$ & 5 & $1(20.0)$ & \multirow[t]{4}{*}{0.385} \\
\hline III/ IV & 72 & $33(45.8)$ & \\
\hline Not specified & 348 & $160(46.0)$ & \\
\hline Missing data & 59 & & \\
\hline \multicolumn{4}{|l|}{ Histological type } \\
\hline Adenocarcinoma & 467 & $220(47.1)$ & \multirow[t]{5}{*}{0.004} \\
\hline Squamous cell carcinoma & 12 & $1(8.3)$ & \\
\hline Large cell carcinoma & 3 & $0(0)$ & \\
\hline Others & 2 & $0(0)$ & \\
\hline Missing data & 0 & & \\
\hline \multicolumn{4}{|l|}{ Degree of differentiation } \\
\hline Well differentiated & 2 & $2(100)$ & \multirow[t]{6}{*}{0.074} \\
\hline Moderately differentiated & 42 & $20(47.6)$ & \\
\hline Poorly differentiated & 33 & $10(30.3)$ & \\
\hline Undifferentiated & 1 & $0(0)$ & \\
\hline Not specified & 41 & $21(51.2)$ & \\
\hline Missing data & 365 & & \\
\hline \multicolumn{4}{|l|}{ Smoking history } \\
\hline Current & 10 & $5(50.0)$ & \multirow[t]{4}{*}{0.191} \\
\hline Former & 3 & $1(33.3)$ & \\
\hline Never & 25 & $17(68.0)$ & \\
\hline Missing data & 446 & $198(44.4)$ & \\
\hline
\end{tabular}


60 years old (48.8\%), in advanced stage patients (45.8\%), in moderately differentiated tumour cells (47.6\%), and in never smokers (68\%). Median age of patients was 60 (range, 21-92).

\section{EGFR mutations detection by Scorpion ARMS}

EGFR mutations were detected in 221 patients (45.7\%) (Figure 1). The most common mutation was deletions in exon 19, comprising 58.9\% (134/231) of all mutations found, followed by $33.8 \%$ (78/231) exon 21 mutation. Thirteen mutations in exon 20 (5.6\%) and four mutations in exon $18(1.7 \%)$ were also detected (Table 3). Interestingly, all mutations in exon 18 were found in the presence of another mutation.

Complex mutation patterns were also detected in the patients. Eight double mutations and one triple mutation were detected in nine patients giving rise to 231 mutations in 221 patients. Among them, five patients had the classical mutation pattern of deletions or $L 858 R$. Two concurrent deletions and $L 858 R$ mutations were also observed (Table 4).

\section{EGFR mutation detection by HRM analysis}

In order to demonstrate the capability of HRM assay in EGFR mutation detection, a total of 236 NSCLC samples were tested by HRM for the detection of EGFR mutations in exon 18 to 21 (Figure 2). The HRM assays yielded 19,
Table 3 Summary of EGFR mutations detected by Scorpion ARMS

\begin{tabular}{llll}
\hline Exon & Mutations & Frequency & Percentage (\%) \\
\hline 18 & G719X & 4 & 1.7 \\
19 & Deletions & 134 & 58.0 \\
20 & S768I & 13 & 5.6 \\
21 & L858R/ L861Q & 80 & 34.6 \\
& Total & 231 & 100 \\
\hline
\end{tabular}

120, 18 and 78 results that were scored as HRM positive in exon 18 to 21 respectively. All mutations identified by SARMS were correctly identified by HRM assays except for 2 samples - one each in exon 19 and 21.

However, HRM indicated more positive samples than Scorpion ARMS for all the EGFR exons. A total of 33 samples were positive only by HRM (Table 5). There were 15, 21, 8 and 4 HRM positive only results from exons 18 to 21 respectively (Table 6). Among these, 1 sample was positive in three HRM assays, 13 samples were positive in two assays, and 19 samples were positive in a single assay.

\section{Discussion}

Currently, direct sequencing is considered the "gold standard" in nucleic acids studies, but its limited sensitivity, high cost and long turnaround time limits its practicality in diagnostic setting. To produce good

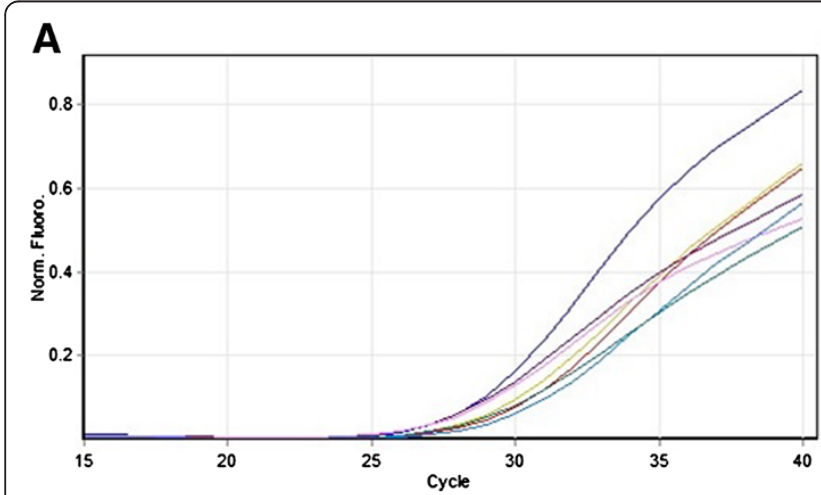

B
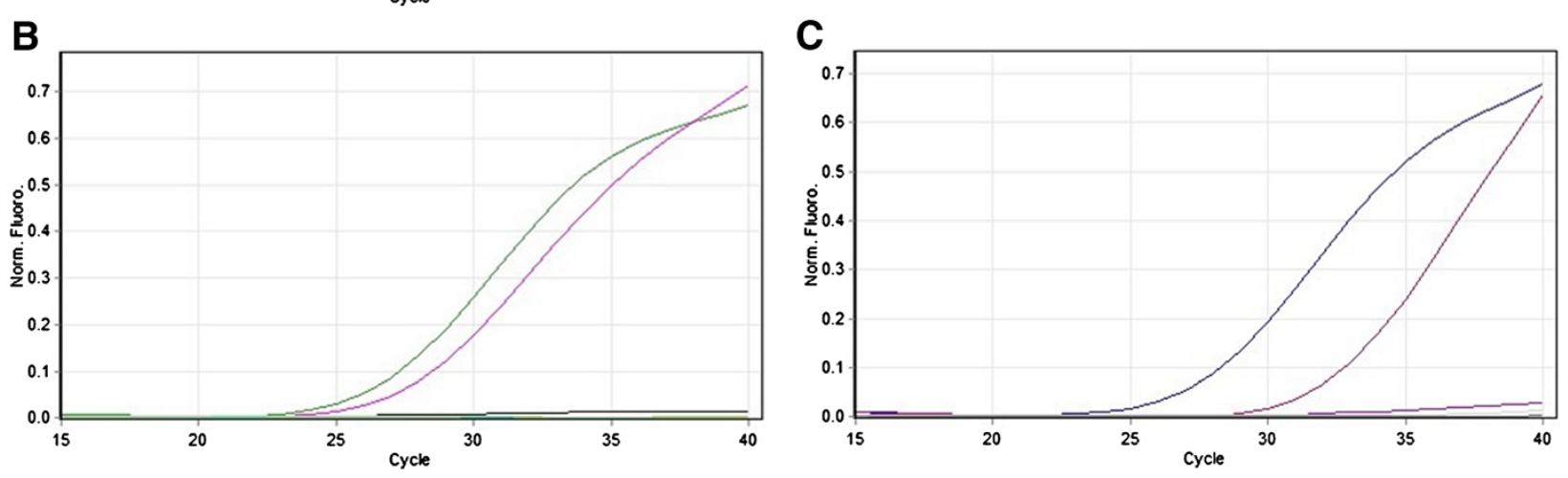

Figure 1 Amplification plots from Scorpion ARMS assay. Panel A: Amplification plots of EGFR positive controls. Panel B: Amplification plot showing the presence of deletions in sample 408. Panel C: Amplification plot showing the presence of L858R mutation in sample 429. 
Table 4 Frequency of EGFR mutations in different gender

\begin{tabular}{|c|c|c|c|}
\hline Mutations & $\begin{array}{l}\text { No. of } \\
\text { samples }\end{array}$ & Male & Female \\
\hline Exon 19 deletions & 128 & 50 & 78 \\
\hline Exon 20 insertions & 5 & 2 & 3 \\
\hline Exon $20 \mathrm{S7681}$ & 2 & 1 & 1 \\
\hline Exon 21 L858R & 74 & 23 & 51 \\
\hline Exon 21 L861Q & 3 & 1 & 2 \\
\hline Exon 18 G719X + Exon 19 deletions & 1 & 0 & 1 \\
\hline Exon 18 G719X + Exon 20 S768l & 2 & 1 & 1 \\
\hline Exon 18 G719X + Exon 21 L861Q & 1 & 1 & 0 \\
\hline Exon 19 deletions + Exon 20 insertions & 3 & 1 & 2 \\
\hline Exon 19 deletions + Exon 21 L858R & 1 & 0 & 1 \\
\hline $\begin{array}{l}\text { Exon } 19 \text { deletions + Exon } 20 \text { insertions + } \\
\text { Exon } 21 \text { L858R }\end{array}$ & 1 & 1 & 0 \\
\hline Total & 221 & 81 & 140 \\
\hline
\end{tabular}

quality sequencing results, tumour samples in sufficient amount and in relatively good condition are required. However, these requirements are often hard to fulfil as lung tumour samples are small and contain only a small proportion of neoplastic cells, therefore resulting in a
Table 5 Comparison of results from scorpion ARMS and HRM assays

\begin{tabular}{llll}
\hline & \multicolumn{2}{l}{ Scorpion ARMS } & \\
\cline { 2 - 3 } HRM & Positive & Negative & Total \\
\hline Positive & 186 & 33 & 219 \\
Negative & 2 & 15 & 17 \\
Total & 188 & 48 & 236
\end{tabular}

reduced sensitivity of sequencing. Besides, special instrumentation are required to perform direct sequencing, which in turn prompted the development of alternative methods that are more sensitive, faster, easier to perform, and at a reduced cost $[11,20]$.

High resolution melting (HRM) is an emerging technique for rapid detection of DNA sequence variation that provides enormous potential to meet clinical demands [21]. HRM involves precise monitoring of the changes in fluorescence caused by the release of an intercalating DNA dye from a double stranded DNA which is denatured by increasing temperature. This technique characterizes the melting or dissociation behaviour of double-stranded PCR products based on the transition of double stranded DNA to single stranded
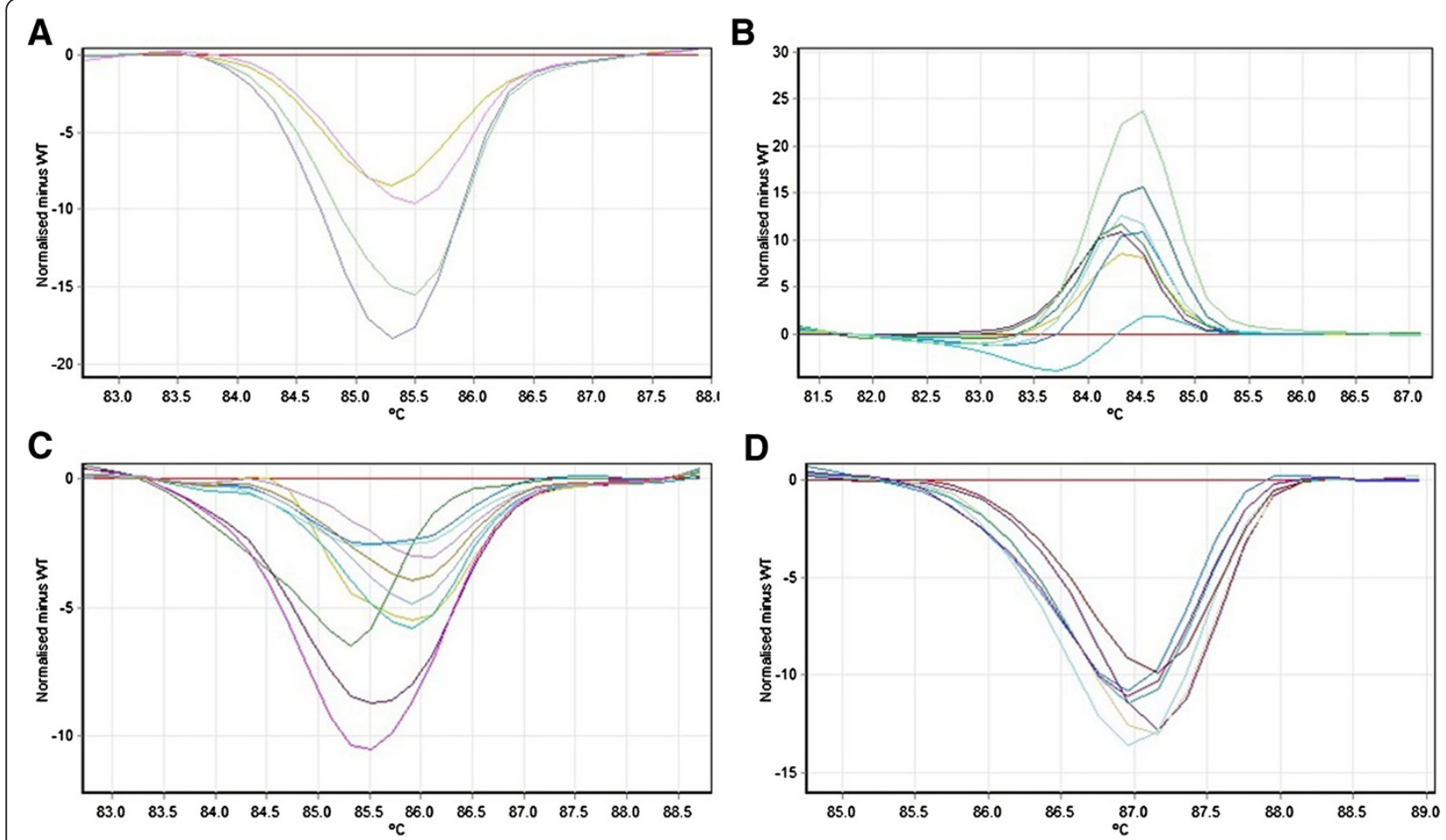

Figure 2 Difference plots of EGFR exons 18-21. Panel A: The difference plot of EGFR exon 18 shows melting profile for four positive samples (S162 in yellow, S455 in pink, S49/12 in green and S87/12 in blue). Panel B: The difference plot of EGFR exon 19 shows melting profiles for seven positive samples (S101 in yellow, S047 in pink, S063 in brown, S552 in green, S065 in blue, S046 in purple and S048 in orange). Panel C: The difference plot of EGFR exon 20 shows melting profile for four positive samples (S13 in yellow, S19 in purple, S28 in green, S68 in pink). Panel D The difference plot of EGFR exon 21 shows melting profile for seven positive samples (S105/12 in purple, S115/12 in light blue, S210/12 in brown, S211/12 in green, S212/12 in dark blue, S217/12 in orange and S220/12 in pink). 
Table 6 Summary of EGFR mutation testing by Scorpion ARMS and HRM

\begin{tabular}{llll}
\hline Exon & Scorpion ARMS positive & HRM positive & HRM positive only \\
\hline 18 & 4 & 19 & 15 \\
19 & 100 & 120 & 21 \\
20 & 10 & 18 & 8 \\
21 & 75 & 78 & 4 \\
\hline
\end{tabular}

DNA with increasing temperature. An advantage of this technique is that it does not involve any post-PCR processing as PCR amplification and melting curve analysis are performed within the same tube, thus reducing the chances of samples contamination and cross-contamination [22]. Compared to the closed tube system of HRM, normal DNA sequencing procedure involves post-PCR processing such as gel electrophoresis and gel purification before the sequencing process, thus increasing the chances of external contamination.

In this study, we compared two methods in the detection of EGFR mutations in NSCLC patients. Our findings showed that EGFR mutations were detectable in genomic samples extracted from FFPE tissue obtained from patients with NSCLC and that both Scorpion ARMS and HRM are useful methods for detection of EGFR mutations. The frequency of EGFR mutation status detected by Scorpion ARMS was statistically significantly more frequent in women (140/233 or $63.3 \%)$ than in men (81/253 or $36.7 \%)$, and more frequent in adenocarcinomas $(220 / 467$ or $47.1 \%)$ than in other histology (1/17 or $5.9 \%)$. Previous studies revealed that EGFR mutations were uncommon in non-adenocarcinomas [14]. In this study, we detected an exon 19 deletion in one female patient with squamous cell carcinoma. The mutation rate $(45.7 \%)$ observed in our study is in concordance with previous findings [6,23-25]. The high overall mutation rate further verifies that the EGFR mutations were more common in Asian population. Evidently, deletions in exon 19 and point mutations in exon 21 are the two most common drug-sensitive EGFR mutations seen in NSCLC. These two mutations made up of $92.7 \%$ of total EGFR mutations detected in this study which is in agreement with previous studies $[18,19,26]$.

Also, we identified 9 patients (4.1\%) with complex mutation patterns. Among the patients with these mutations, 4 cases were found in Chinese patients, 3 in Malay patients, 1 in Indian and 1 other ethnicity. Complex EGFR mutations were reported to be more common in Asian lung cancer patients. However, information about the effects of complex EGFR mutations on patients' response to EGFR TKI was very limited. Furthermore, findings from previous studies varied between each other. Tam et al. (2009) reported that EGFR double mutants showed attenuated responses to gefitinib compared to single classical mutations [27]. On the contrary, a study by Wu et al. (2008) showed that patients with complex EGFR mutations with the classical mutation pattern response better to gefitinib than those without the classical mutation pattern. Also, these patients showed longer progression free survival and overall survival times after receiving the therapy [13].

Based on the results from Scorpion ARMS, we selected a total of 236 samples, consisting both EGFR positive and negative mutation status, and performed HRM assays on these samples to assess its capability in detecting EGFR mutation as precision in identifying mutations is the fundamental in all mutation scanning methods. This study shows the reliability of HRM analysis in EGFR mutation detection in a panel of selected samples. All mutations identified by Scorpion ARMS were correctly identified in HRM analysis except for 2 samples - one from exon 19 assay and another from exon 21 assay. One possible explanation for this is the low level of mutation in the samples which were beyond the limit of HRM detection. The Scorpion ARMS and results from HRM assays agreed that 186 of 236 were positive and 15 were negative. The interrater reliability for the methods was found to be statistically significant with a value of Kappa $=0.40(\mathrm{p}<.0 .001)$ which indicates fair agreement between the two methods [28].

One of the drawbacks of extracting DNA from FFPE material is the low yield. Thus, additional PCR cycles were needed to achieve sufficient amplification. In a study by Do et al. (2008), it was found that insufficient amplification causes a right shift of the melting curves relative to the wild-type curves in normalized plots. And by increasing the amplification cycle number to 60 , the melting curves were corrected and can be reliably compared to the wild-type during analysis [20]. Depending on the degree of DNA degradation, the amount of amplifiable templates varies in each sample although all were adjusted to the same concentration $(5 \mathrm{ng} / \mu \mathrm{l})$.

\section{Conclusions}

In conclusion, both Scorpion ARMS and HRM were successfully performed on genomic samples extracted from FFPE tumours. Overall, HRM compares well with the Scorpion ARMS kit. HRM indicated more positive samples than Scorpion ARMS for all the EGFR exons. Nevertheless, it remains to be determined whether these results were true mutation or merely false positive.

\section{Competing interests}

The authors declare that they have no competing interests.

\section{Authors' contributions}

CYK designed the project, and gave critical evaluation of the manuscript; PR validated all pathological slides; TNSY performed research, analyzed the data, and draft the paper. All authors read and approved the final manuscript. 


\section{Acknowledgements}

We thank Sime Darby Medical Centre laboratory for FFPE tissue processing. This project was supported by funding from Research University Grant Scheme (04-02-11-1375RU).

\section{Author details}

'Department of Biomedical Sciences, Faculty of Medicine and Health Sciences, Universiti Putra Malaysia, 43400, Serdang, Selangor, Malaysia. ${ }^{2}$ Monash University, Jalan Lagoon Selatan, Bandar Sunway 46150Selangor, Malaysia. ${ }^{3}$ Department of Pathology, Faculty of Medicine and Health Sciences, Universiti Putra Malaysia, 43400, Serdang, Selangor, Malaysia. ${ }^{4}$ Department of Community Health, Faculty of Medicine and Health Sciences, Universiti Putra Malaysia, 43400, Serdang, Selangor, Malaysia.

Received: 7 December 2012 Accepted: 12 April 2013 Published: 16 April 2013

\section{References}

1. Jemal A, Bray F, Center MM, Ferlay J, Ward E, Forman D: Global cancer statistics. CA Cancer J Clin 2011, 61:69-90.

2. Lim GCC, Rampal S, Halimah Y (Eds): Cancer Incidence in Peninsular Malaysia, 2003-2005. Kuala Lumpur: National Cancer Registry; 2008.

3. Stella GM, Luisetti M, Inghilleri S, Cemmi F, Scabini R, Zorzetto M, Pozzi E: Targeting EGFR in non-small-cell lung cancer: lessons, experiences, strategies. Respir Med 2012, 106:173-183.

4. Su Z: Epidermal growth factor receptor mutation-guided treatment for lung cancers: where are we now? Thoracic Cancer 2011, 2:1-6.

5. Lynch TJ, Bell DW, Sordella R, Gurubhagavatula S, Okimoto RA, Brannigan BW, Harris PL, Haserlat SM, Supko JG, Haluska FG, Louis DN, Christiani DC, Settleman J, Haber DA: Activating mutations in the epidermal growth factor receptor underlying responsiveness of non-small-cell lung cancer to gefitinib. N Engl J Med 2004, 350:2129-2139.

6. Paez JG, Jänne PA, Lee JC, Tracy S, Greulich H, Gabriel S, Herman P, Kaye FJ, Lindeman N, Boggon TJ, Naoki K, Sasaki H, Fujii Y, Eck MJ, Sellers WR, Johnson BE, Meyerson M: EGFR mutations in lung cancer: correlation with clinical response to gefitinib therapy. Science 2004, 304:1497.

7. Pao W, Miller V, Zakowski M, Doherty J, Politi K, Sarkaria I, Singh B, Heelan R, Rusch V, Fulton L, Mardis E, Kupfer D, Wilson R, Kris M, Varmus H: EGF receptor gene mutations are common in lung cancers from "never smokers" and are associated with sensitivity of tumors to gefitinib and erlotinib. PNAS 2004, 101(36):13306-13311.

8. He M, Capelletti M, Nafa K, Yun CH, Arcila ME, Miller VA, Ginsberg MS, Zhao B, Kris MG, Eck MJ, Jänne PA, Ladanyi M, Oxnard GR: EGFR exon 19 insertions: a new family of sensitizing EGFR mutations in lung adenocarcinoma. Clin Cancer Res 2012, 18(6):1790-1797.

9. Inoue A, Suzuki T, Fukuhara T, Maemondo M, Kimura Y, Morikawa N, Watanabe H, Saijo Y, Nukiwa T: Prospective phase ii study of gefitinib for chemotherapy- naïve patients with advanced non-small-cell lung cancer with epidermal growth factor receptor gene mutations. J Clin Oncol 2006, 24(21):3340-3346.

10. Mukohara T, Engelman JA, Hanna NH, Yeap BY, Kobayashi S, Lindeman N, Halmos B, Pearlberg J, Tsuchihashi Z, Cantley LC, Tenen DG, Johnson BE, Jänne PA: Differential effects of gefi tinib and cetuximab on non - smallcell lung cancers bearing epidermal growth factor receptor mutations. J Natl Cancer Inst 2005, 97(16):1185-1194.

11. Nomoto K, Tsuta K, Takano T, Fukui T, Yokozawa K, Sakamoto H, Yoshida T, Maeshima AM, Shibata T, Furuta K, Ohe Y, Matsuno Y: Detection of EGFR mutations in archived cytologic specimens of non-small cell lung cancer using high-resolution melting analysis. Am J Clin Pathol 2006, 126:608-615.

12. Yasuda $\mathrm{H}$, Kobayashi $\mathrm{S}$, Costa DB: EGFR exon 20 insertion mutations in non-small-cell lung cancer: preclinical data and clinical implications. Lancet Oncol 2012, 13:e23-31.

13. Wu SG, Chang YL, Hsu YC, Wu JY, Yang CH, Yu CJ, Tsai MF, Shih JY, Yang PC: Good response to gefitinib in lung adenocarcinoma of complex epidermal growth factor receptor (EGFR) mutations with the classical mutation pattern. Oncologist 2008, 13:1276-1284.

14. Hsieh MH, Fang YF, Chang WC, Kuo HP, Lin SY, Liu HP, Liu CL, Chen HC, Ku YC, Chen YT, Chang YH, Chen YT, Hsi BL, Tsai SF, Huang SF: Complex mutation patterns of epidermal growth factor receptor gene associated with variable responses to gefitinib treatment in patients with non-small cell lung cancer. Lung Cancer 2006, 53:311-322.

15. Marchetti A, Del Grammastro M, Filice G, Felicioni L, Rossi G, Graziano P, Sartori G, Leone A, Malatesta S, lacono M, Guetti L, Viola P, Mucilli F,

Cuccurullo F, Buttitta F: Complex mutations \& subpopulations of deletions at exon 19 of EGFR in NSCLC revealed by next generation sequencing: potential clinical implications. PLoS One 2012, 7(7):e42164.

16. Salto-Tellez M, Tsao MS, Shih JY, Thongprasert S, Lu S, Chang GC, Au JSK, Chou TY, Lee JS, Shi YK, Radzi A, Kang JH, Kim SW, Tan SY, Yang JCH: Clinical and testing protocols for the analysis of epidermal growth factor receptor mutations in East Asian patients with non-small cell lung cancer: a combined clinical-molecular pathological approach. $J$ Thorac Oncol 2011, 6(10):1663-1669.

17. Leary AF, Castro DGD, Nicholson AG, Ashley S, Wotherspoon A, O'Brien ME, Popat $\mathrm{S}$ : Establishing an EGFR mutation screening service for non-small cell lung cancer - Sample quality criteria and candidate histological predictors. Eur J Cancer 2012, 48:61-67.

18. Kimura H, Kasahara K, Kawaishi M, Kunitoh H, Tamura T, Holloway B, Nishio $\mathrm{K}$ : Detection of epidermal growth factor receptor mutations in serum as a predictor of the response to gefitinib in patients with non-small-cell lung cancer. Clin Can Res 2006, 12(13):3915-3921.

19. Horiike A, Kimura H, Nishio K, Ohyanagi F, Satoh Y, Okumura S, Ishikawa Y, Nakagawa K, Horai T, Nishio M: Detection of epidermal growth factor receptor mutation in transbronchial needle aspirates of non-small cell lung cancer. Chest 2007, 131(6):1628-1634.

20. Do H, Krypuy M, Mitchell PL, Fox SB, Dobrovic A: High resolution melting analysis for rapid and sensitive EGFR and KRAS mutation detection in formalin fixed paraffin embedded biopsies. BMC Cancer 2008, 8:142.

21. Krypuy M, Newnham GM, Thomas DM, Conron M, Dobrovic A: High resolution melting analysis for the rapid and sensitive detection of mutations in clinical samples: KRAS codon 12 and 13 mutations in nonsmall cell lung cancer. BMC Cancer 2006, 6:295.

22. Norambuena PA, Copeland JA, Krenková P, Štambergová A, Macek M Jr: Diagnostic method validation: High resolution melting (HRM) of small amplicons genotyping for the most common variants in the MTHFR gene. Clin Biochem 2009, 42(12):1308-1316.

23. Shigematsu H, Lin L, Takahashi T, Nomura M, Suzuki M, Wistuba II, Fong KM, Lee H, Toyooka S, Shimizu N, Fujisawa T, Feng Z, Roth JA, Herz J, Minna JD, Gazdar AF: Clinical and biological features associated with epidermal growth factor receptor gene mutations in lung cancers. JNCl 2005, 97(5):339-346.

24. Mitsudomi T, Kosaka T, Endoh H, Horio Y, Hida T, Mori S, Hatooka S, Shinoda $M$, Takahashi T, Yatabe Y: Mutations of the epidermal growth factor receptor gene predict prolonged survival after gefitinib treatment in patients with non-small-cell lung cancer with postoperative recurrence. J Clin Oncol 2005, 23(11):2513-2520.

25. Takano T, Ohe Y, Sakamoto H, Tsuta K, Matsuno Y, Tateishi U, Yamamoto S, Nokihara H, Yamamoto N, Sekine I, Kunitoh H, Shibata T, Sakiyama T, Yoshida T, Tamura T: Epidermal growth factor receptor gene mutations and increased copy numbers predict gefitinib sensitivity in patients with recurrent non-small-cell lung cancer. J Clin Oncol 2005, 23(28):6829-6837.

26. John T, Liu G, Tsao MS: Overview of molecular testing in non-small-cell lung cancer: mutational analysis, gene copy number, protein expression and other biomarkers of EGFR for the prediction of response to tyrosine kinase inhibitors. Oncogene 2009, 28:S14-S23.

27. Tam IYS, Leung ELH, Tin VPC, Chua DTT, Sihoe ADL, Cheng LC, Chung LP, Wong MP: Double EGFR mutants containing rare EGFR mutant types show reduced in vitro response to gefitinib compared with common activating missense mutations. Mol Cancer Ther 2009, 8(8):2142-2151.

28. Landis JR, Koch GG: The measurement of observer agreement for categorical data. Biometrics 1977, 33(1):159-174.

\section{doi:10.1186/1423-0127-20-22}

Cite this article as: Shi Yeen et al.: Detection of epidermal growth factor receptor mutations in formalin fixed paraffin embedded biopsies in Malaysian non-small cell lung cancer patients. Journal of Biomedical Science 2013 20:22. 